\title{
On the problems and Countermeasures of College Dance Teaching
}

\author{
SHI Yan \\ Jingchu institute college of art, Jingmen city of Hubei Province,448000,China \\ shiyanjm@126.com
}

Keywords: college dance; classroom teaching; present situation; problems; Countermeasures

\begin{abstract}
Dance is a vivid display of spiritual civilization and artistic civilization. Dance performance can not only bring the audience to enjoy the visual, but also subtle influence on the audience's aesthetic, resonate with the audience's inner world. As an effective approach to the construction of socialist spiritual civilization, college dance teaching can enhance students' aesthetic ability and artistic accomplishment fundamentally, which is in line with the overall improvement of students' comprehensive quality. This paper briefly introduces the current situation of the dance teaching in Colleges and universities in China, and puts forward the corresponding solutions to the problems encountered in the actual teaching process, in order to provide help to improve the teaching effect.
\end{abstract}

\section{Introduction}

Dance belongs to the category of comprehensive art, through the performer's body and certain dance movements to achieve the art, ideas, aesthetic display. In many factors of quality education in Colleges and universities, arts education, dance teaching occupies an important position, in line with the college students comprehensive quality requirements, is conducive to cultivating students' good quality, therefore, we should pay enough attention to. Colleges and universities should adhere to the basic principles, combined with the actual teaching situation and the existing problems, the teaching content, teaching ideas, teaching methods to carry out bold innovation, to seek the rapid and healthy development of dance teaching.

\section{An analysis of the present situation of dance teaching in Colleges and universities in China}

Dance education started late, teaching ideas and methods obsolete. Compared to other sports and art education courses in Colleges and universities, dance education started late. In addition to the sports colleges and universities and professional colleges and universities, science and engineering, colleges and universities to set up a relatively late dance classes, and relatively few hours. Especially in science and engineering colleges and universities, the number of male and female students vary greatly, the physical education curriculum is often based on traditional content, such as football, basketball, Tai Chi, dance teaching courses, the rate is very low. In addition, affected by a variety of factors, the development of college teaching funds for dance teaching, teaching site construction, professional teachers and other aspects of the development is lagging behind. Dance teaching in Colleges in teaching content and mode of education by the professional colleges have adopted the basic introduction of the way, ignoring the non dance students' deficiency in learning ability, basic dance level, leading to the teaching content does not conform to the actual situation of students, the teaching methods are too traditional. At present, the domestic colleges and universities have a more in-depth understanding of the importance of dance education, dance teaching content in the proportion of physical education curriculum is on the rise.

Dance education has developed rapidly in recent years. In recent years, with the deepening of the reform of education, the situation of dance education in Colleges and universities has been greatly improved. Dance education curriculum in Colleges and universities has gradually increased, and set on the dance dance course teaching facilities funding, teachers professionalism are more and more attention to the past problems, reform in education, to meet the basic needs of dance education. Some of the economic strength of colleges and universities began to invest in the construction of modern 
high-quality teaching venues, equipped with professional teaching equipment, and strive to enhance the degree of specialization of dance teaching. In addition, through the organization of university art troupe dance association, and other forms, combined with the current actual demand and the cultural life of college students learning situation of dance programs, and starred in the holiday party, campus party, was a great success. The dance teaching in Colleges and universities in China is getting rid of the difficulties, and gradually embarked on the road of rapid development.

\section{Problems existing in the current teaching of dance}

College dance teaching content old students learning enthusiasm is not high. Due to the late start, short development time, lack of awareness of the importance of teaching, lack of teaching resources and weak teachers and other factors, the quality of dance teaching in domestic universities can not be guaranteed. In most colleges and universities, the teaching mode and teaching content of the professional colleges and universities are directly introduced into the dance teaching

The curriculum is not reasonable, the teaching content and the basic situation of the students' poor fit, teaching methods are too old, and carry out the teaching practice of traditional education mode and thinking process can not jump out of detention, there is error setting on the role of teachers and students, teacher training is too strong a dominant position, ignoring the students main body status. Dance teachers in the teaching process is only responsible for theoretical knowledge teaching, and then organize students to learn dance movements and skills, do not pay attention to cultivate and improve students' aesthetic ability, learning ability, performance ability, causes the student to grasp even the dance moves, still can not really understand the spirit and artistic composition contains, their comprehensive artistic level cannot get better development.

Dance teaching teachers lack. In the process of the development of college dance teaching, the teachers' professional quality, teaching ability and the teaching ideas always have a decisive influence on the teaching effect. Under the actual situation, some of the university dance teaching teachers can not be weak, the teachers have the support and professional quality is not up to standard, can not meet the teaching needs. In addition, teachers lack the opportunity and platform to continue learning, improve teaching ability and professional quality. Some colleges and universities and even the existence of non dance teachers are responsible for the teaching of dance. Can not provide protection for the specific implementation of dance teaching, from the knowledge system, teaching methods, teaching time and other aspects of the development of dance teaching.

Dance teaching mode monotonous teaching means backward, lack of teaching resources. College dance teaching curriculum is insufficient, the content is single and the teaching mode is too traditional. In the process of teaching, teachers still use the method of instilling the main, without introducing heuristic teaching mode. The lack of learning interest and subjective initiative of students is not conducive to the cultivation of creative and artistic ability. In addition, the teaching method is old, and the practice is less. Dance practice teaching is still in the knowledge of simple instruction, not with the demonstration of the action of knowledge, increase students' learning difficulties, is not conducive to the students to understand and master the knowledge in teaching, practical work is not high. There are many reasons for this kind of situation, in which the lack of teaching resources occupy the main position. The actual situation, the existing teaching resources can not meet the demand of dance teaching work, the lack of education funds, education field makes teachers only pay attention to students' mastery of theoretical knowledge and memory, to guide the students to translate knowledge into skills, resulting in students of dance courses producing boring psychological trouble. Not conducive to the cultivation of high-quality personnel. In addition, many colleges and universities teaching the blind pursuit of the expansion of the scale, set up a lot of professional courses, messy, lack of attention to the dance courses, lack of awareness of the importance of dance teaching in college quality education, art education, teaching dance elective courses tend to be included and set for the few hours of teaching. This kind of cognitive error limits the investment of college dance teaching to a large extent, which directly affects the construction and improvement of teachers' strength. Some colleges and universities will even set up dance teaching courses, the 
purpose of the purchase of teaching equipment resources to set up to cope with higher inspection. The above situation hinders the development of dance education in Colleges and universities, and has a serious negative impact on students' learning and teaching quality.

\section{Measures to improve the level of College Dance Teaching}

Teaching students in accordance with their aptitude. To carry out the dance teaching work in Colleges and universities should strengthen the teaching reform, get rid of the bad part of the traditional concept, clear the students in the teaching process with the main body status, strengthen students' participation in classroom teaching, to stimulate interest in learning and initiative. Compared with other professional courses, dance teaching has its own unique characteristics. On the one hand, students should be able to master the dance movements and related skills, on the other hand, it should also emphasize the students' imagination, innovation ability, performance ability, art appreciation ability of the comprehensive promotion. Learning dance needs to pay attention to the basic skills, but also have a strong perseverance and perseverance. Therefore, we must adhere to the concept of people-oriented, respect for the dominant position of students, to enhance the impact of various factors. In the actual teaching process, teachers should keep on students' care and attention to cultivate students' correct dance learning attitude, fully arouse their interest in learning, for students, guide the students to actively participate in dance teaching activities, through the joint efforts of both sides to enhance the effect of education. In addition, the practice of college dance teaching requires teachers to create a relaxed and good learning atmosphere for students, and strive to tap the potential of students. In addition to respect for students, clear the main body of learning, teachers should also be individualized in accordance with the individual characteristics of students. Each student in the learning ability, understanding ability, the basis of dance and other differences, the need for teachers with appropriate teaching methods for training. For students with weak foundation, the basic skills training should be strengthened and the basic training should be strengthened. For students with higher basic skills, higher requirements should be put forward to promote students' further improvement. In particular, pay attention to the cultivation of their dance skills and artistic perception. Strengthen the guidance, deepen students' understanding of the nature of the dance, so that students can really feel the beauty of art contained in the dance, cultivate students' aesthetic ability and artistic accomplishment. Teachers should also encourage students to use the knowledge and skills to change the existing dance movements, thereby stimulating students' imagination and creativity.

Continue to strengthen the construction of dance teachers. In order to promote the healthy and rapid development of dance teaching in Colleges and universities, and improve the education level and quality of teaching, we must attach importance to the enhancement of teachers' strength. Although the students occupy the dominant position in the teaching process, the leading role of the teachers will still have a decisive influence on the teaching effect. Therefore, the dance education work must give teachers dominant enough attention, with full respect for teachers in the teaching process to occupy the position, the maximum degree with the reasonable way of teacher's leading role. Colleges and universities should take flexible measures to improve the professional quality of teachers, teaching ability and related skills. For example, hire experts with rich experience and performing high-profile school seminars or lectures, organize teachers to participate in the dance to the teaching level and enhancing the professional competence for the purpose of training teachers to participate in teaching activities, selected places, experience communication and communication. Only to ensure the ability of university dance teachers professional quality and teaching standards, can through the guide will teach students, fundamentally to provide protection for the dance teaching effect and quality, better guide the students feel the charm of the dance curriculum.

Optimizing teaching means to enrich teaching resources. In the process of carrying out traditional dance teaching, teachers often use the words and deeds of the way of teaching. First demonstration to explain, and then require students to imitate. As a kind of comprehensive art, dance shows the spirit, art and beauty through the performer's body and specific actions. Therefore, there are many disadvantages in traditional teaching methods in the teaching of dance. In order to meet the 
needs of teaching, teachers must actively introduce a variety of modern teaching methods, and strive to improve the quality of teaching and teaching effectiveness. For example, the introduction of multimedia technology in the process of education, the implementation of a specific dance action targeted to explain the difficulty of the action to explain the decomposition. On the one hand, this kind of teaching method can reduce the difficulty of learning, on the other hand, it can save teaching time. Multi media teaching technology can realize the integration of action, music and video, give the teaching activity rhythm, effectively stimulate the enthusiasm of students, enhance the attraction of dance teaching to students. Compared with the rest of the course, the dance course has a high degree of particularity, the teaching process involves not only a lot of theoretical knowledge, but also covers a variety of types of dance movements. The conventional teaching mode, teaching skills and actions show dance teachers often through personal demonstration of the way, but affected by the demonstration time shortage, high complexity and difficult movements and other factors, it is difficult for students to do meticulous observation on action. The introduction of multimedia technology solves this problem perfectly. The work of teaching, teachers can use images, video and other ways to guide the students to observe the features and details of the dance, also can use the method to explain the frequency of slow motion, the key and difficult points to teach the students, reduce the difficulty of learning, deepen their impression. By repeatedly playing video, in-depth analysis of dance movements, and then guide students to strengthen practice. In addition, the dance teaching has very high practical requirements, efforts should be made to provide students with colleges and universities in the process of teaching work performance opportunities, let the student obtain the real stage feeling, will master the theoretical knowledge and skill of dance art fusion. First of all, we can organize students to participate actively in the performing arts activities, to achieve the combination of classroom teaching and practice. Secondly, regular appointment with rich performance experts experience to school students for demonstration, or arrangement with students on the same stage, to stimulate students' enthusiasm for learning, let students learn to cooperate with each other in more practical skills. Finally, the dance teachers give full play to the guiding role, to encourage students to master the theoretical knowledge and skills to create programs to promote practical ability.

\section{Summary}

At the present stage, there are some problems in the process of carrying out the dance teaching in the domestic universities, which is mainly reflected in the teaching concept and teaching methods, which seriously affects the teaching effect of the dance. In view of this kind of objective problem, it is necessary to actively change the concept from the point of view, to introduce more abundant teaching methods, to increase the investment in the construction of teachers, and to lay the foundation for improving the teaching effect. Adhere to the aesthetic education and quality education advanced ideas, promote the process of teaching reform, out of the traditional teaching mode and teaching ideas, to promote the success of the transformation of dance teaching in Colleges and universities.

\section{Reference}

[1] Wang Yuanyuan. Problems existing in the teaching of children's dance composition in preschool education major in Colleges and universities and improvement strategies [J]. northern music, 2016,36 (17): 187-187.

[2] Wang. On the value of dance elements in the public music teaching in Colleges and universities and the implementation of [J]. music creation, 2016, (6): 189-191.

[3] Wang Yaping. Study on the problems and improvement measures in the teaching of folk dance in the northeast of China [J]. Chinese national exposition, 2016, (): 36-37.

[4] Cao Lihong [J]. China Chapter, problems and optimizing strategies of teaching in Colleges and universities face dance practice in China 2013 (6): 239 
[5] Li Guoxian. Strengthen the music and dance fusion, realize the education, the teaching reform of dance [J]. age of 2016, (13): 205 